\title{
Cold Stratification Delays Germination of Black Huckleberry Seeds
}

\author{
Danny L. Barney ${ }^{1}$ \\ Department of Plant, Soil, and Entomological Sciences, University of Idaho, \\ 2105 N. Boyer Avenue, Sandpoint, ID 83864
}

\section{Bahman Shafii and William J. Price \\ Statistical Programs, College of Agriculture, University of Idaho, Moscow, ID 83844-2337}

Additional index words. Vaccinium membranaceum, Vaccinium globulare, globe huckleberry, thin-leaved huckleberry, germination model, logistic growth curve

Most Vaccinium species germinate without cold stratification (Dirr and Heuser, 1987), but little research has been published on the physiology of seed germination for $V$. membranaceum. Dirr and Heuser (1987) referred to findings by the Arnold Arboretum that $V$. membranaceum seeds germinate without pretreatment, but details on that work were absent. Minore et al. (1979) stated that stratification was unnecessary for $V$. membranaceum seed germination, but provided no details of supporting research. McLean (1967) conducted stratification trials on V. membranaceum and found that stratification at $1^{\circ} \mathrm{C}$ for $30,60,90,120$, or $150 \mathrm{~d}$ failed to improve germination. McLean reported only on maximum germination percentages without describing other parameters of germination. Furthermore, statistical treatments supporting the conclusions were absent. The following experiment was conducted to document the effects of cold stratification on germination dynamics of $V$. membranaceum.

Ripe $V$. membranaceum berries were collected in August 1996 from the Kaniksu National Forest in Bonner County, Idaho at an elevation of $1600 \mathrm{~m}$. Seeds were extracted, cleaned, air-dried at room temperature for $7 \mathrm{~d}$ to a moisture content of $8.0 \%$ on a fresh weight basis, and stored at 0 to $4{ }^{\circ} \mathrm{C}$ for $\approx 180 \mathrm{~d}$. Dry seeds were sieved and those $500-600 \mu \mathrm{m}$ in diameter were retained. V. membranaceum

Received for publication 8 June 2000. Accepted for publication 16 Nov. 2000. Published with the approval of the Idaho Agricultural Experiment Station as manuscript No. 99749. Funding was provided by the Univ. of Idaho, U.S. Dept. of Agriculture, Agricultural Research Service Northwest Center for Small Fruit Research, and Hatch Act funds, project IDA01153. Mention of trade or company names does not imply endorsement by the Idaho Agricultural Experiment Station nor criticism of similar products not named. The cost of publishing this paper was defrayed in part by the payment of page charges. Under postal regulations, this paper therefore must be hereby marked advertisement solely to indicate this fact.

${ }^{1}$ To whom requests for reprints should be addressed. E-mail address: dbarney@uidaho.edu averages $30 \mathrm{mg}$ per 100 seeds (Vander Kloet, 1988). Lots of 100 seeds were surface sterilized for $20 \mathrm{~min}$ in $0.5 \%$ sodium hypochlorite solution and rinsed in sterile water. Previous tests (unpublished) in our laboratory established that surface sterilization for $20 \mathrm{~min}$ had little, if any, effect on maximum cumulative germination, as compared to nonsterilized controls. Seeds were placed on moist, sterile filter paper inside $10 \times 1.5-\mathrm{cm}$ plastic petri dishes, with eight dishes (replications) containing 100 seeds per treatment.

Dishes sealed with plastic film were placed inside a refrigerator at 1 to $3{ }^{\circ} \mathrm{C}$ for $0,14,28$, 42 , or $56 \mathrm{~d}$. After stratification, the dishes were moved into an environmental chamber set at $28^{\circ} \mathrm{C}$ day $/ 23^{\circ} \mathrm{C}$ night. Light was provided 12 $\mathrm{h} / \mathrm{d}$ by $20 \mathrm{~W}$ wide-spectrum plant and aquarium fluorescent tubes. Seeds were examined under a magnifying lens and those exhibiting any radicle emergence were counted and removed from the dishes every $7 \mathrm{~d}$. Sterile water was added to the dishes as necessary to keep the filter paper moist.

Cumulative germination was modeled using a logistic growth curve model, as described by Shafii and Barney (2001):

$$
\mathrm{y}=\mathrm{M}\left\{1+\exp \left[-\mathrm{K}^{*}(\mathrm{t}-\mathrm{L})\right]\right\}^{-1}
$$

where $\mathrm{y}$ is the cumulative percentage of germination at time $\mathrm{t}, \mathrm{M}$ the asymptote (theoretical maximum for $\mathrm{y}$ ), $\mathrm{L}$ the time to $50 \%$ germination ( $\mathrm{T} 50$ ), and $\mathrm{K}$ being proportional to the rate of increase in germination. Separate logistic models were estimated for each of the five stratification treatments. Model estimations, assessments, and comparisons were carried out using the methods outlined in Shafii (1995) and Shafii and Barney (2001).

Stratification at 1 to $3{ }^{\circ} \mathrm{C}$ delayed germination (Table 1). The T50 estimate for nonstratified seeds was $27 \mathrm{~d}$, while T50 values for stratification treatments varied from 32 to $39 \mathrm{~d}$, averaging $9 \mathrm{~d}$ longer than for nonstratified seeds. Statistical contrasts between treatment and control T50 estimates were all highly significant. The germination rate parameter, $\mathrm{K}$, also increased with stratification, but the differences were statistically significant for only the 28- and 56-d treatments. Stratification increased germination uniformity for seeds germinating within $28 \mathrm{~d}$ of sowing.

Maximum cumulative germination ranged from $63 \%$ (56 d stratification) to $70 \%$ ( $28 \mathrm{~d}$ stratification). Differences between stratified and nonstratified seeds were significant $(P<$ 0.003 ) only for the 14- and 28-d treatments. While statistically significant, the importance of these differences in practical propagation is limited. Stratification for $14 \mathrm{~d}$ increased the germination percentage from $65 \%$ to $69 \%$, whereas stratification for $28 \mathrm{~d}$ increased germination to $70 \%$. In associated trials (Shafii and Barney, 2001), fresh, nondried, nonstratified $V$.membranaceum seeds germinated at percentages about equal to those observed in this trial. The mechanism by which stratification at 1 to $3{ }^{\circ} \mathrm{C}$ delayed germination remains to be determined.

Stratification at 1 to $3{ }^{\circ} \mathrm{C}$ for 14 or $28 \mathrm{~d}$ slightly increased maximum germination percentages for $V$. membranaceum. Any stratification from 14 to $56 \mathrm{~d}$, however, delayed the onset of germination. For propagation purposes, stratification is unnecessary and could delay seedling emergence.

Table 1. Parameter estimates for stratification treatments (moist chilling at 1 to $3^{\circ} \mathrm{C}$ ) to Vaccinium membranaceum seeds.

\begin{tabular}{lccc}
\hline $\begin{array}{l}\text { Treatment } \\
\text { duration }(\mathrm{d})\end{array}$ & $\mathrm{L}(\mathrm{d})^{\mathrm{z}}$ & $\mathrm{K}^{\mathrm{y}}$ & $\mathrm{M}(\%)^{\mathrm{x}}$ \\
\hline 0 & 27 & 0.8 & 65 \\
14 & $32^{*}$ & 0.9 & $69^{*}$ \\
28 & $39^{*}$ & $1.1^{*}$ & $70^{*}$ \\
42 & $37^{*}$ & 1.0 & 65 \\
56 & $36^{*}$ & $1.1^{*}$ & 63 \\
\hline
\end{tabular}

${ }^{\mathrm{z}} \mathrm{L}=\mathrm{T} 50$; days from sowing to $50 \%$ germination. ${ }^{\mathrm{y}} \mathrm{K}=$ germination rate index .

${ }^{\mathrm{x}} \mathrm{M}=$ maximum cumulative percentage of germination.

*Parameter estimates that are significantly different from those of the control $(P \leq 0.05)$.

\section{Literature Cited}

Dirr, M.A. and C.W. Heuser. 1987. The reference manual of woody plant propagation: From seed to tissue culture. Varsity Press, Athens, Ga.

McLean, A. 1967. Germination of forest range species from southern British Columbia. J. Range Mgt. 20:321-322.

Minore, D. 1972. The wild huckleberries of Washington and Oregon: A dwindling resource, $\mathrm{p}$. 6-9. In: U.S. Dept. Agr. For. Serv. Res. Paper 143. Pacific Northwest For. and Range Expt. Sta., Portland, Ore.

Minore, D., A.W. Smart, and M.E. Dubrasich. 1979. Huckleberry ecology and management research in the Pacific Northwest. Research Note PNW-236. U.S. Dept. Agr. For. Serv. Pacific Northwest For. and Range Expt. Sta., Portland, Ore.

Shafii, B. 1995. Diagnostic procedures for nonlinear growth models. Proc. Amer. Statistical Assoc., Section on Statistical Education, p. 3847 Amer. Stat. Assoc. Alexandria, Va.

Shafii, B. and D.L. Barney. 2001. Drying and cold storage affect germination of black huckleberry Seeds. HortScience. 36:145-147.

Vander Kloet, S.P. 1988. The genus Vaccinium in North America. Pub 1828. Res. Br., Agr. Canada, Canadian Govt. Publ. Centre, Ottawa. 